\title{
Optimal pharmacological therapy in ST-elevation myocardial infarction-a review
}

\section{A review of antithrombotic therapies in STEMI}

\author{
R. S. Hermanides' · S. Kilic' • A. W. J. van 't Hof ${ }^{2,3}$
}

Published online: 23 April 2018

(c) The Author(s) 2018

\begin{abstract}
Antithrombotic therapy is an essential component in the optimisation of clinical outcomes in patients with ST-elevation myocardial infarction (STEMI) undergoing primary percutaneous coronary intervention. There are currently several intravenous anticoagulant drugs available for primary percutaneous coronary intervention. Dual antiplatelet therapy comprising aspirin and P2Y12 inhibitor represents the cornerstone treatment for STEMI. However, these effective treatment strategies may be associated with bleeding complications. Compared with clopidogrel, prasugrel and ticagrelor are more potent and predictable, which translates into better clinical outcomes. Therefore, these agents are the first-line treatment in primary percutaneous coronary intervention. However, patients can still experience adverse ischaemic events, which might be in part attributed to alternative pathways triggering thrombosis. In this review, we provide a critical and updated review of currently available antithrombotic therapies used in patients with STEMI undergoing primary PCI. Finding a balance that minimises both thrombotic and bleeding risk is difficult, but crucial. Further randomised trials for this optimal balance are needed.
\end{abstract}

Keywords STEMI · Antithrombotic therapy

\section{Introduction}

Acute ST-elevation myocardial infarction (STEMI) is a major cause of mortality worldwide. The rapid restoration of blood flow in the occluded culprit coronary artery with primary percutaneous coronary intervention (PCI) will prevent heart failure, preserves ventricular function and reduces mortality [1-4]. The cause of STEMI is erosion or rupture of an atherosclerotic plaque with subsequent platelet adherence, activation, aggregation, and activation of the clotting cascade and downstream myocardial ischaemia and necrosis after complete coronary artery occlusion [5]. The main elements involved in this process are platelet and co-

\footnotetext{
A. W. J. van 't Hof

v.r.c.derks@isala.nl

Isala Heart Centre, Zwolle, The Netherlands

2 Department of Cardiology, Maastricht UMC, Maastricht, The Netherlands

3 Department of Cardiology, Zuyderland Medical Centre (Heerlen location), Heerlen, The Netherlands
}

agulation factors (Fig. 1). It is very important to find a balance in pharmacological management of STEMI that will minimise thrombotic risk and bleeding risk. In this article, we review currently available antithrombotic therapies that can be used in patients with STEMI who are undergoing primary PCI.

\section{Antiplatelet and anticoagulant medications for STEMI}

\section{Classification of anticoagulants (Tab. 1)}

1. Unfractionated heparin

2. Low-molecular-weight heparin

3. Bivalirudin

4. Thrombin receptor antagonist protease-activated receptor - vorapaxar

5. Factor Xa inhibitor

- rivaroxaban 


\section{KEY MESSAGE}

- Selecting the right antiplatelet and antithrombotic agent is of paramount importance in the treatment of STEMI patients undergoing primary PCI.

- Adjunctive pharmacotherapy should be tailored to the individual patient, based on assessment of ischaemic and bleeding risk.

- With regard to antiplatelet therapy in STEMI, the recommend first-line P2Y12 inhibitors in the setting of primary $\mathrm{PCl}$ are ticagrelor and prasugrel.

- In patients with a low bleeding risk the use of heparin, with or without GPI, as an anticoagulant seems to be cost-effective and has been associated with better clinical outcome when compared to bivalirudin.

Fig. 1 Mechanism of thrombus formation during STEMI, and targets of available antithrombotic agents. After plaque rupture, a complex mechanism of thrombus formation is mediated. COX cyclooxygenase, $T P$ thromboxane prostanoid, STEMI ST-elevation myocardial infarction

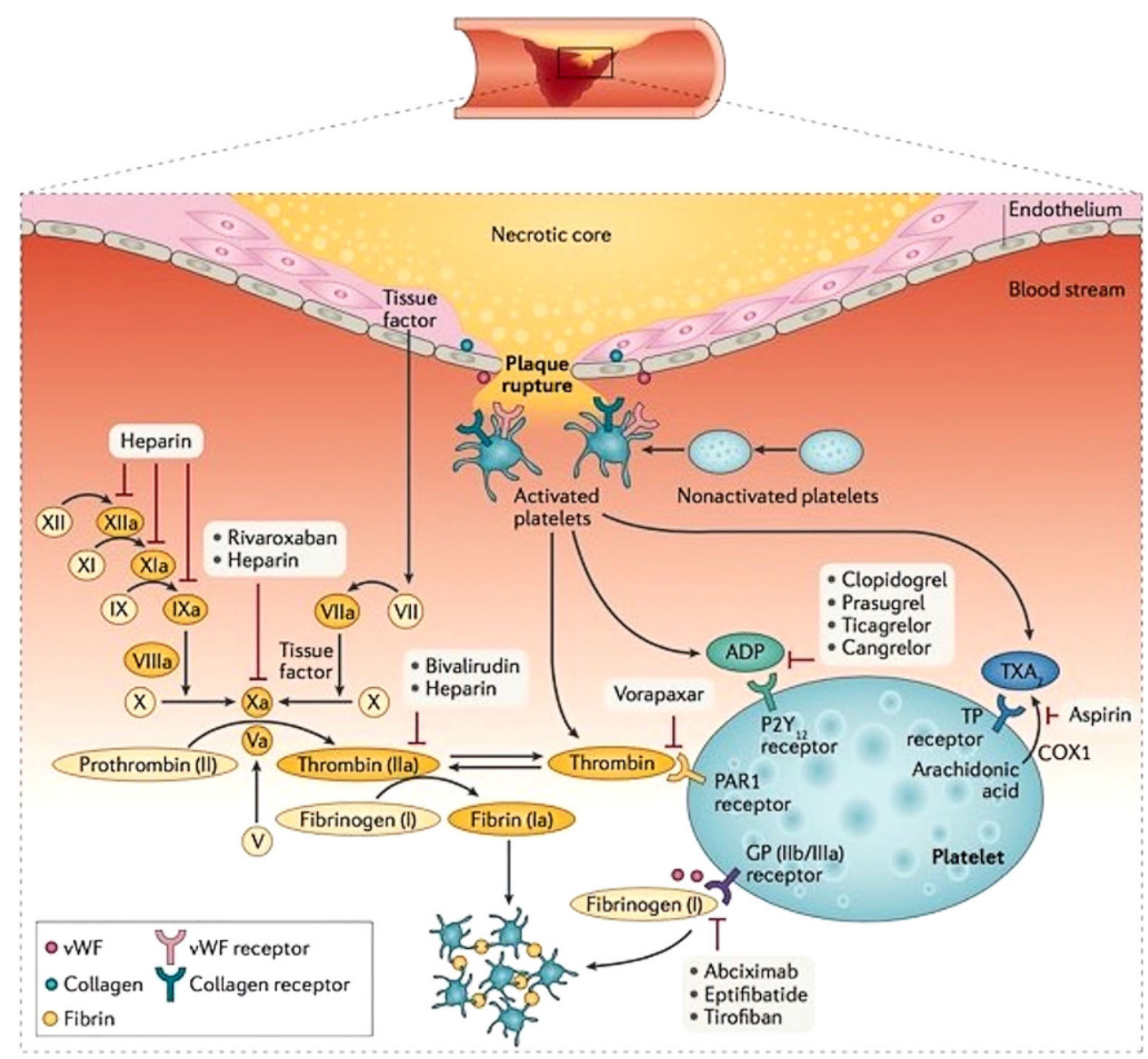

\section{Classification of antiplatelet agents}

\section{Anticoagulant therapy before and during primary $\mathrm{PCl}$}

1. Aspirin

2. $\mathrm{P} 2 \mathrm{Y} 12$ receptor inhibitors

- clopidogrel, prasugrel (irreversible inhibitors)

- cangrelor and ticagrelor (reversible inhibitors)

3. Glycoprotein IIb/IIIa inhibitors

- tirofiban, abciximab, eptifibatide

\section{Unfractionated heparin}

Based on several small randomised trials, anticoagulation with unfractionated heparin became an accepted and important therapy for STEMI, especially before and during the PCI procedure [6]. The major anticoagulant effect of 
Table 1 Pharmacological properties of anticoagulants in STEMI

\begin{tabular}{llll}
\hline & UFH & Enoxaparin & Bivalirudin \\
\hline Administration route & Intravenous & Intravenous, subcutaneous & Intravenous \\
Factor Xa:Ila inhibition & $1: 1$ & $3-4: 1$ & Only IIa \\
$\begin{array}{l}\text { Action independent of an- } \\
\text { tithrombin }\end{array}$ & No & No & Yes \\
Nonspecific binding & Yes & Partial & No \\
Variable PK/PD measures & Yes & Yes (<unfractionated heparin) & No \\
Inhibits fibrin-bound thrombin & No & No & Yes \\
Effect on platelets & Activation & Activation & Inhibition \\
Half-life & $\sim 60$ min & $90-120$ min & 25 min \\
Risk of HITT & Yes & Yes (<unfractionated heparin) & No \\
Dose in PPCI & $70-100 \mathrm{U} / \mathrm{kg}$ bolus without GPIs; & $0.5 \mathrm{mg} / \mathrm{kg}$ intravenous bolus & $0.75 \mathrm{mg} / \mathrm{kg}$ intravenous bolus; \\
& $50-70 \mathrm{U} / \mathrm{kg}$ bolus with GPIs & & $1.75 \mathrm{mg} / \mathrm{kg} / \mathrm{h}$ infusion \\
Reversal agent & Protamine sulfate & No & No \\
\hline
\end{tabular}

STEMI ST-elevation myocardial infarction, HITT heparin induced thrombocytopenia and thrombosis, $P P C I$ primary percutaneous coronary intervention, GPIs glycoprotein IIb/IIIa inhibitors, $P K$ pharmacokinetic, $P D$ pharmacodynamics $U F H$ unfractionated heparin

unfractionated heparin is based on inactivation of thrombin and activated factor $\mathrm{X}$ (factor $\mathrm{Xa}$ ) reacts by binding to antithrombin III, an endogenous inhibitor of factor Xa and thrombin IIa. This binding induces a conformational change in antithrombin 3 , which markedly accelerates its ability to inactivate these factors. The recommended periprocedural dosing in patients who also receive a glycoprotein IIb/IIIa inhibitor is 50 to $70 \mathrm{U} / \mathrm{kg}$ (target activated clotting time $[\mathrm{ACT}]>200 \mathrm{~s}$ ); in patients not receiving a GP IIb/ IIIa inhibitor, the recommended peri-procedural dosing is 60 to $100 \mathrm{U} / \mathrm{kg}$ (target ACT, 250 to $350 \mathrm{~s}$ ) [3, 4]. Currently, unfractionated heparin has a Class I indication (level of evidence (LOE):C) for anticoagulation during primary PCI in the new European Society of Cardiology (ESC) guideline [3]. A major limitation of unfractionated heparin is the increased risk of heparin-induced thrombocytopenia, a serious, potentially lethal, and immunologically mediated adverse reaction.

\section{Low-molecular-weight heparin}

Low-molecular-weight heparins seem to offer a better clinical efficacy in STEMI when administered intravenously as compared with unfractionated heparin. In the ATOLL study [7], 900 STEMI patients were randomly assigned to receive an intravenous bolus of $0.5 \mathrm{mg} / \mathrm{kg}$ enoxaparin or unfractionated heparin before primary PCI. Comparison of enoxaparin versus unfractionated heparin in the ATOLL study showed that enoxaparin was associated with a significant reduction in the secondary endpoint (a composite of death, recurrent acute coronary syndrome or urgent revascularisation) and a significant reduction in individual endpoints, including mortality, major bleeding, and urgent revascularisation. It is recommended to use enoxaparin, preferentially via intravenous route, $0.5 \mathrm{mg} / \mathrm{kg}$. Based on a potential benefit in the secondary endpoint, the new ESC guidelines give a Class IIa (LOE: A) indication for enoxaparin in this setting [3, 4].

The OASIS-6 trial, which evaluated fondaparinux (factor X inhibitor) use in STEMI patients, received a lot of criticism because of the heterogeneity in the medical and invasive treatment of the enrolled patients and showed a high rate of catheter thrombosis and coronary complications [8]. Fondaparinux is not recommended in the ESC guidelines as background anticoagulant for primary PCI (Class III; LOE: B).

\section{Bivalirudin}

Bivalirudin is a direct inhibitor of soluble and clotbound thrombin [9]. It has a rapid onset of action and a half-life of $25 \mathrm{~min}$ and is therefore given as an intravenous infusion. The results of several bivalirudin studies (HEATPPCI, MATRIX, BRAVE-4, EUROMAX, BRIGHT) have led to discussions about its added value (Tab. 2). Recent meta-analyses have demonstrated no mortality benefit but fewer bleeding complications in bivalirudin users [9-14]. The EUROMAX trial is a randomised clinical trial comparing bivalirudin versus heparin plus optional glycoprotein $\mathrm{IIb} / \mathrm{III}$ inhibitors in patients undergoing primary PCI for STEMI. The 1-year mortality outcomes showed that the total number of deaths was identical in both study arms (59 events in each) with no appreciable differences in the two treatment arms between 30 days and 1 year [15], despite a bivalirudin-associated reduction in the occurrence of the study's primary endpoint which was death or major bleeding at 30 days. The most recent publication, the VALIDATE-SWEDEHEART, a registry-based, randomised, controlled trial that compared bivalirudin with heparin monotherapy in patients with STEMI or non-ST- 
Table 2 Major trials of bivalirudin versus UFH in STEMI

\begin{tabular}{|c|c|c|c|c|c|}
\hline & HORIZONS-AMI & EUROMAX & HEAT-PPCI & BRIGHT & MATRIX-STEMI \\
\hline \multicolumn{6}{|l|}{ Trial design } \\
\hline $\begin{array}{l}\text { Patient popula- } \\
\text { tion }\end{array}$ & $\begin{array}{l}\text { 3,602 STEMI under- } \\
\text { going PPCI }\end{array}$ & $\begin{array}{l}\text { 2,218 STEMI trans- } \\
\text { ported for PPCI }\end{array}$ & $\begin{array}{l}\text { 1,812 STEMI under- } \\
\text { going PPCI }\end{array}$ & $\begin{array}{l}\text { 2,194 acute MI un- } \\
\text { dergoing emergency } \\
\text { PCI }(87.7 \% \text { STEMI) }\end{array}$ & $\begin{array}{l}\text { 4,010 STEMI under- } \\
\text { going PPCI }\end{array}$ \\
\hline $\begin{array}{l}\text { Type of hep- } \\
\text { arin }\end{array}$ & UFH & UFH or enoxaparin & $\mathrm{UFH}$ & UFH & UFH \\
\hline Heparin dose & $\begin{array}{l}60 \mathrm{U} / \mathrm{kg} \text { with sub- } \\
\text { sequent boluses } \\
\text { targeted to ACT of } \\
200-250 \mathrm{~s}\end{array}$ & $\begin{array}{l}\text { UFH: } 100 \mathrm{U} / \mathrm{kg} \text { with- } \\
\text { out GPI or } 60 \mathrm{U} / \mathrm{kg} \\
\text { with GPI. Enoxa- } \\
\text { parin: } 0.5 \mathrm{mg} / \mathrm{kg}\end{array}$ & $70 \mathrm{U} / \mathrm{kg}$ & $\begin{array}{l}100 \mathrm{U} / \mathrm{kg} \text { in } \\
\mathrm{UFH} \text {-only group; } \\
60 \mathrm{U} / \mathrm{kg} \text { in heparin } \\
\text { plus tirofiban group }\end{array}$ & $\begin{array}{l}70-100 \mathrm{U} / \mathrm{kg} \text { without } \\
\text { GPI or } 50-70 \mathrm{U} / \mathrm{kg} \\
\text { with GPI }\end{array}$ \\
\hline $\begin{array}{l}\text { GPI use in } \\
\text { heparin group }\end{array}$ & $\begin{array}{l}\text { Routine ( } 97.7 \% \text { of } \\
\text { patients) }\end{array}$ & $\begin{array}{l}\text { Routine or bailout } \\
\text { ( } 69 \% \text { of patients) }\end{array}$ & $\begin{array}{l}\text { Bailout ( } 14 \% \text { of } \\
\text { patients) }\end{array}$ & $\begin{array}{l}\text { Bailout ( } 5.6 \% \text { of pa- } \\
\text { tients) in UFH-only } \\
\text { group; routine } \\
(100 \%) \text { in UFH plus } \\
\text { tirofiban group }\end{array}$ & $\begin{array}{l}\text { Routine or bailout } \\
\text { ( } 25.9 \% \text { of patients) }\end{array}$ \\
\hline $\begin{array}{l}\text { GPI use in } \\
\text { bivalirudin } \\
\text { group }\end{array}$ & $\begin{array}{l}\text { Bailout }(7.5 \% \text { of } \\
\text { patients) }\end{array}$ & $\begin{array}{l}\text { Bailout }(11.5 \% \text { of } \\
\text { patients) }\end{array}$ & $\begin{array}{l}\text { Bailout ( } 14 \% \text { of } \\
\text { patients) }\end{array}$ & $\begin{array}{l}\text { Bailout ( } 4.4 \% \text { of } \\
\text { patients) }\end{array}$ & $\begin{array}{l}\text { Bailout ( } 4.6 \% \text { of } \\
\text { patients) }\end{array}$ \\
\hline $\begin{array}{l}\text { Post-PCI bi- } \\
\text { valirudin infu- } \\
\text { sion }\end{array}$ & $\begin{array}{l}\text { None (but could be } \\
\text { continued at low } \\
\text { doses if clinically } \\
\text { indicated) }\end{array}$ & $\begin{array}{l}4 \mathrm{~h} \text { after PCI at } \\
0.25 \mathrm{mg} / \mathrm{kg} / \mathrm{h} \text {; con- } \\
\text { tinuation of PCI dose } \\
\text { was also permitted } \\
(22.5 \%)\end{array}$ & None & $\begin{array}{l}30 \mathrm{~min}-4 \mathrm{~h} \text { after PCI } \\
(\text { mean } 180 \mathrm{~min}) \text { at } \\
\text { PCI dose }\end{array}$ & $\begin{array}{l}\text { Patients randomised } \\
1: 1 \text { to receive or not } \\
\text { receive post-PCI in- } \\
\text { fusion (full dose for } \\
\text { up to } 4 \mathrm{~h} \text { or reduced } \\
\text { dose of } 0.25 \mathrm{mg} / \mathrm{kg} / \mathrm{h} \\
\text { for } \geq 6 \mathrm{~h} \text { ) }\end{array}$ \\
\hline $\begin{array}{l}\mathrm{P} 2 \mathrm{Y} 12 \text { recep- } \\
\text { tor inhibitor }\end{array}$ & $\begin{array}{l}\text { Clopidogrel } \\
300-600 \mathrm{mg}\end{array}$ & $\begin{array}{l}\text { Clopidogrel }(50 \%) \text {, } \\
\text { prasugrel }(30 \%) \text {, or } \\
\text { ticagrelor }(20 \%)\end{array}$ & $\begin{array}{l}\text { Clopidogrel }(11 \%) \text {, } \\
\text { prasugrel }(27 \%) \text {, or } \\
\text { ticagrelor }(62 \%)\end{array}$ & $\begin{array}{l}\text { Clopidogrel } \\
300-600 \mathrm{mg}\end{array}$ & $\begin{array}{l}\text { Clopidogrel }(29 \%) \text {, } \\
\text { prasugrel }(31 \%) \text {, or } \\
\text { ticagrelor }(30 \%)\end{array}$ \\
\hline Radial access & No & $47 \%$ of patients & $81 \%$ of patients & $78 \%$ of patients & $\begin{array}{l}50 \% \text { (randomised } \\
1: 1 \text { to radial versus } \\
\text { femoral) }\end{array}$ \\
\hline $\begin{array}{l}\text { Primary end } \\
\text { point }\end{array}$ & $\begin{array}{l}\text { NACE (major bleed- } \\
\text { ing or MACE [death, } \\
\text { reinfarction, TVR } \\
\text { for ischaemia, and } \\
\text { stroke]) at } 30 \text { days; } \\
\text { non-CABG-related } \\
\text { major bleeding at } \\
30 \text { days }\end{array}$ & $\begin{array}{l}\text { Death or non- } \\
\text { CABG-related major } \\
\text { bleeding at } 30 \text { days }\end{array}$ & $\begin{array}{l}\text { Efficacy: MACE (al- } \\
\text { l-cause death, CVA, } \\
\text { reinfarction, or ad- } \\
\text { ditional unplanned } \\
\text { TLR) at } 28 \text { days. } \\
\text { Safety: major bleed- } \\
\text { ing at } 28 \text { days }\end{array}$ & $\begin{array}{l}\text { NACE (MACE [al- } \\
\text { 1-cause death, rein- } \\
\text { farction, ischaemi- } \\
\text { a-driven TVR, or } \\
\text { stroke] or any bleed- } \\
\text { ing) at } 30 \text { days }\end{array}$ & $\begin{array}{l}\text { MACE (death, MI, } \\
\text { or stroke) at } 30 \text { days; } \\
\text { NACE (MACE or } \\
\text { major bleeding) at } \\
30 \text { days }\end{array}$ \\
\hline $\begin{array}{l}\text { Bleeding defi- } \\
\text { nition }\end{array}$ & Protocol-defined & Protocol-defined & BARC type $3-5$ & BARC & BARC type 3 or 5 \\
\hline \multicolumn{6}{|l|}{ Study results } \\
\hline $\begin{array}{l}\text { Primary end } \\
\text { point(s) }\end{array}$ & $\begin{array}{l}\text { NACE: bivalirudin } \\
9.2 \% \text { vs. UFH } 12.1 \% \\
(P=0.005) \text {; non- } \\
\text { CABG-related major } \\
\text { bleeding: bivalirudin } \\
4.9 \% \text { vs. UFH } 8.3 \% \\
(P<0.001)\end{array}$ & $\begin{array}{l}\text { Bivalirudin } 5.1 \% \text { vs. } \\
\text { UFH } 8.5 \% \\
(P=0.001)\end{array}$ & $\begin{array}{l}\text { MACE: bivalirudin } \\
8.7 \% \text { vs. UFH } 5.7 \% \\
(P=0.02) \text {; major } \\
\text { bleeding: bivalirudin } \\
3.5 \% \text { vs. UFH } 3.1 \% \\
(P=0.59)\end{array}$ & $\begin{array}{l}\text { Bivalirudin } 8.8 \% \text { vs. } \\
\text { heparin } 13.2 \% \text { vs. } \\
\text { UFH plus tirofiban } \\
17.0 \%(P<0.001)\end{array}$ & $\begin{array}{l}\text { MACE: bivalirudin } \\
5.9 \% \text { vs. UFH } 6.5 \% \\
(P=0.43) \text {; NACE: } \\
\text { bivalirudin } 7.0 \% \text { vs. } \\
\text { UFH } 8.2 \%(P=0.13)\end{array}$ \\
\hline MACE & $\begin{array}{l}\text { Bivalirudin } 5.4 \% \text { vs. } \\
\text { UFH } 5.5 \%(P=0.95)\end{array}$ & $\begin{array}{l}\text { Bivalirudin } 6.0 \% \text { vs. } \\
\text { UFH } 5.5 \%(P=0.64)\end{array}$ & $\begin{array}{l}\text { See primary end } \\
\text { point }\end{array}$ & $\begin{array}{l}\text { Bivalirudin } 5.0 \% \text { vs. } \\
\text { UFH } 5.8 \% \text { vs. UFH } \\
\text { plus tirofiban } 4.9 \% \\
(P=0.83)\end{array}$ & $\begin{array}{l}\text { See primary end } \\
\text { point }\end{array}$ \\
\hline
\end{tabular}


Table 2 (Continued)

\begin{tabular}{|c|c|c|c|c|c|}
\hline & HORIZONS-AMI & EUROMAX & HEAT-PPCI & BRIGHT & MATRIX-STEMI \\
\hline Major bleeding & $\begin{array}{l}\text { See primary end } \\
\text { point }\end{array}$ & $\begin{array}{l}\text { Bivalirudin } 2.6 \% \\
\text { vs. UFH } 6.0 \% \\
(P<0.001)\end{array}$ & $\begin{array}{l}\text { See primary end } \\
\text { point }\end{array}$ & $\begin{array}{l}\text { BARC type } 3-5 \text { : } \\
\text { bivalirudin } 0.5 \% \text { vs. } \\
\text { UFH } 1.5 \% \text { vs. UFH } \\
\text { plus tirofiban } 2.1 \% \\
(P=\text { NA })\end{array}$ & $\begin{array}{l}\text { Bivalirudin } 1.7 \% \\
\text { vs. UFH } 2.8 \% \\
(P=0.019)\end{array}$ \\
\hline $\begin{array}{l}\text { Acute stent } \\
\text { thrombosis } \\
(\leq 24 \mathrm{~h})\end{array}$ & $\begin{array}{l}\text { Bivalirudin } 1.3 \% \\
\text { vs. UFH } 0.3 \% \\
(P<0.001)\end{array}$ & $\begin{array}{l}\text { Bivalirudin } 1.1 \% \\
\text { vs. UFH } 0.2 \% \\
(P=0.007)\end{array}$ & $\begin{array}{l}\text { Bivalirudin } 2.9 \% \\
\text { vs. UFH } 0.9 \% \\
(P=0.007)\end{array}$ & $\begin{array}{l}\text { Bivalirudin } 0.3 \% \text { vs. } \\
\text { UFH } 0.3 \% \text { vs. UFH } \\
\text { plus tirofiban } 0.3 \% \\
(P=\text { NA })\end{array}$ & $\begin{array}{l}\text { Bivalirudin } 0.9 \% \text { vs. } \\
\text { UFH } 0.5 \%(P=0.10)\end{array}$ \\
\hline
\end{tabular}

STEMI ST-elevation myocardial infarction, $U F H$ unfractionated heparin, $C A B G$ coronary artery bypass grafting, GPI glycoprotein IIb/ IIIa inhibitors, PPCI primary percutaneous coronary intervention, MACE major adverse cardiac events, NACE net adverse clinical events, $M I$ myocardial infarction, $B A R C$ bleeding academic research consortium, $N A$ not available, TVR target vessel revascularisation, TLR target lesion revascularisation

elevation myocardial infarction (NSTEMI) who underwent PCI (predominantly radial PCI) and received treatment with high-intensity platelet inhibitors, did not find a difference with respect to the rate of death, repeat myocardial infarction, or major bleeding events during 180 days of followup [16]. Bivalirudin, with or without previous heparin therapy, has a Class IIa (LOE: A) indication in the new 2017 ESC STEMI guidelines, that also specify that at PCI the recommended dosing is an initial bolus of $0.75 \mathrm{mg} / \mathrm{kg}$ and an infusion of $1.75 \mathrm{mg} / \mathrm{kg} / \mathrm{hr}$ during PCI. Following PCI, an infusion of $0.25 \mathrm{mg} / \mathrm{kg} / \mathrm{hr}$ can be continued if clinically appropriate [3, 4].

\section{Antiplatelet therapy before and during primary $\mathrm{PCI}$}

\section{Aspirin}

Aspirin irreversibly blocks both cyclo-oxygenase 1 (COX1) and COX-2 and inhibits the production of thromboxane A2 [17]. Thromboxane A2 stimulates further platelet activation and aggregation, which is produced by activated platelets. The large ISIS-2 trial showed that use of aspirin was associated with decreased rates of re-infarctions and non-fatal strokes at mid-term follow-up, with the highest benefit seen in patients undergoing PCI [18].

Given its established benefits in secondary prevention [19], aspirin should be used indefinitely in all patients with STEMI. The dosage of aspirin is topic of discussion. In respect of the first few days of treatment, the CURRENT-OASIS 7 trial [20] failed to demonstrate a difference in hard clinical outcomes when comparing low doses $(75-100 \mathrm{mg} /$ day) or relatively high doses of $300-325 \mathrm{mg} /$ day. There were, however, fewer gastro-intestinal bleeds with the lower doses. The ESC recommends administering an initial loading dose of $150-500 \mathrm{mg}$ of oral or intravenous acetylsalicylic acid, unless contraindicated, followed by a life-long maintenance dose of $75-100 \mathrm{mg}$ daily (Class I; LOE: B) (Tab. 3; [3]). Patients who are truly intolerant to aspirin may instead receive clopidogrel (75 mg/day) as long-term secondary prevention [21].

\section{P2Y12 receptor inhibitors}

Clopidogrel The second-generation thienopyridine clopidogrel is the most widely used $\mathrm{P} 2 \mathrm{Y} 12$ receptor inhibitor [22]. The clinical use of clopidogrel in acute coronary syndrome has been investigated in the large CURE trial, which evidenced a significant reduction in a composite of cardiovascular death, recurrent acute myocardial infarction or stroke when a $300 \mathrm{mg}$ loading dose followed by a $75 \mathrm{mg}$ daily dose of the drug was added to aspirin versus aspirin alone $(9.3 \%$ versus $11.4 \%$; $p<0.001)$. Furthermore, the CURRENT-OASIS 7 trial showed benefit of a $600 \mathrm{mg}$ loading dose instead of a $300 \mathrm{mg}$ loading dose [20]. However, there is growing concern about response variability in patients with clopidogrel use [23]. Genetic testing before starting clopidogrel therapy, in high-risk STEMI patients, and platelet function testing, in those who suffer adverse events, may facilitate the monitoring of clopidogrel treatment, and is currently being investigated [24]. The current recommendations by the ESC state a loading dose of $600 \mathrm{mg}$ of clopidogrel followed by a maintenance dose of $75 \mathrm{mg}$ daily (or $150 \mathrm{mg}$ until day 8) only when prasugrel or ticagrelor are either not available or contraindicated (Class I; LOE: A) (Tab. 3; [3]).

Prasugrel Prasugrel is an oral, third-generation thienopyridine. Like clopidogrel, it is a prodrug, and thus needs to be metabolised via cytochrome $\mathrm{P} 450$ in the liver to produce an active metabolite. The PRINCIPLE-TIMI trial showed that a $60 \mathrm{mg}$ loading dose and $10 \mathrm{mg}$ maintenance dose of prasugrel achieved superior results in terms of platelet inhibition compared with a $600 \mathrm{mg}$ loading dose and $150 \mathrm{mg}$ maintenance dose of clopidogrel [25]. The TRITON-TIMI 38 study compared a $60 \mathrm{mg}$ loading dose followed by $10 \mathrm{mg}$ daily maintenance dose of prasugrel with a $300 \mathrm{mg}$ loading 
Table 3 Pharmacological properties of oral antithrombotic therapy in/after STEMI

\begin{tabular}{|c|c|c|c|c|c|c|}
\hline & Aspirin & Clopidogrel & Prasugrel & Ticagrelor & Vorapaxar & Rivaroxaban \\
\hline Target & COX1 & $\mathrm{P} 2 \mathrm{Y} 12$ receptor & $\mathrm{P} 2 \mathrm{Y} 12$ receptor & $\mathrm{P} 2 \mathrm{Y} 12$ receptor & PAR1 & Factor $\mathrm{Xa}$ \\
\hline Type of blockade & Irreversible & Irreversible & Irreversible & Reversible & Reversible & Reversible \\
\hline Dose & $\begin{array}{l}150-325 \mathrm{mg} \\
\mathrm{LD} ; 81-100 \mathrm{mg} \\
\text { once-daily MD }\end{array}$ & $\begin{array}{l}600 \mathrm{mg} \mathrm{LD} ; 75 \mathrm{mg} \\
\text { once-daily MD }\end{array}$ & $\begin{array}{l}60 \mathrm{mg} \mathrm{LD} \\
10 \mathrm{mg} \text { once- } \\
\text { daily MD }\end{array}$ & $\begin{array}{l}180 \mathrm{mg} \mathrm{LD} ; \\
90 \mathrm{mg} \text { twice- } \\
\text { daily MD }\end{array}$ & $\begin{array}{l}2.08 \mathrm{mg} \text { once- } \\
\text { daily MD }\end{array}$ & $\begin{array}{l}2.5 \mathrm{mg} \text { twice- } \\
\text { daily MD }\end{array}$ \\
\hline Prodrug & No & Yes & Yes & No & No & No \\
\hline Onset of action & $60 \mathrm{~min}$ & $2-8 h$ & $30 \mathrm{~min}-4 \mathrm{~h}$ & $30 \min -4 h$ & $>12 \mathrm{hll}$ & $2-4 h$ \\
\hline Offset of action & 7-10 days & $7-10$ days & 7-10 days & 3-5 days & 4-8 weeks & $12 \mathrm{~h}$ \\
\hline Drug interactions & NSAIDs & CYP2C19 inhibitors & No & $\begin{array}{l}\text { CYP3A in- } \\
\text { hibitors or in- } \\
\text { ducers, drugs } \\
\text { using P-glyco- } \\
\text { protein trans- } \\
\text { porter }\end{array}$ & $\begin{array}{l}\text { CYP3A in- } \\
\text { hibitors or } \\
\text { inducers, drugs } \\
\text { using P-glyco- } \\
\text { protein trans- } \\
\text { porter }\end{array}$ & $\begin{array}{l}\text { CYP3A4 in- } \\
\text { hibitors or } \\
\text { inducers, } \\
\text { P-glycopro- } \\
\text { tein transporter } \\
\text { inhibitors }\end{array}$ \\
\hline $\begin{array}{l}\text { Timing of admin- } \\
\text { istration }\end{array}$ & $\begin{array}{l}\text { Immediately af- } \\
\text { ter presentation }\end{array}$ & $\begin{array}{l}\text { At presentation or at } \\
\text { time of primary PCI }\end{array}$ & $\begin{array}{l}\text { At presentation } \\
\text { or at time of } \\
\text { primary PCI }\end{array}$ & $\begin{array}{l}\text { At presentation } \\
\text { or at time of } \\
\text { primary PCI }\end{array}$ & $\begin{array}{l}\text { After stabilisa- } \\
\text { tion }\end{array}$ & $\begin{array}{l}\text { After stabilisa- } \\
\text { tion }(>24 \mathrm{~h} \text { after } \\
\text { admission) }\end{array}$ \\
\hline Contraindications & Hypersensitivity & $\begin{array}{l}\text { Hypersensitivity, } \\
\text { active pathological } \\
\text { bleeding }\end{array}$ & $\begin{array}{l}\text { Prior CVA, high } \\
\text { risk of bleeding, } \\
\text { hypersensitivity }\end{array}$ & $\begin{array}{l}\text { Prior ICH, high } \\
\text { risk of bleeding, } \\
\text { severe hepatic } \\
\text { dysfunction, } \\
\text { hypersensitivity }\end{array}$ & $\begin{array}{l}\text { Prior ICH or } \\
\text { CVA, high risk } \\
\text { of bleeding, } \\
\text { hypersensitivity }\end{array}$ & $\begin{array}{l}\text { Prior } \\
\mathrm{CVA}, \mathrm{CrCl} \\
<15 \mathrm{ml} / \mathrm{min} \text {, } \\
\text { high bleeding } \\
\text { risk, severe } \\
\text { hepatic dys- } \\
\text { function, treat- } \\
\text { ment with other } \\
\text { anticoagulant, } \\
\text { hypersensitivity }\end{array}$ \\
\hline
\end{tabular}

STEMI ST-elevation myocardial infarction, $C O X 1$ cyclo-oxygenase-1, $P A R-1$ protease-activated receptor-1, $L D$ loading dose, $M D$ maintenance dose, NSAIDs non-steroidal anti-inflammatory drugs, $P C I$ percutaneous coronary intervention, $C V A$ cerebrovascular accident, $I C H$ intracerebral haemorrhage, $\mathrm{CrCl}$ creatinine clearance

dose and $75 \mathrm{mg}$ daily maintenance dose of clopidogrel, with the loading dose administered after coronary angiography [26]. The trial demonstrated a significant reduction of the composite endpoint of cardiovascular death, non-fatal acute myocardial infarction and non-fatal stroke in the prasugrel group $(9.9 \%$ versus $12.1 \% ; p<0.001)$, with early survival advantages after only 3 days persisting at a mean followup of 14.5 months. The ESC recommends a $60 \mathrm{mg}$ loading dose and $10 \mathrm{mg}$ daily maintenance dose of prasugrel in patients undergoing PCI (Class I; LOE: A) after visualisation of the coronary arteries (Tab. $3 ;[3,4]$ ). Of note, prasugrel is contraindicated in patients with prior stroke/transient ischaemic attack and its use is generally not recommended in patients aged $\geq 75$ years or in patients with lower body weight $(<60 \mathrm{~kg})$.

Ticagrelor Ticagrelor is a class of adenosine diphosphate (ADP) blockers, triazolopyrimidines, which act as ADP analogues directly binding to P2Y12 causing allosteric reversible blockage of the receptor. The PLATO trial [27], comparing a standard $300-600 \mathrm{mg}$ loading dose and $75 \mathrm{mg}$ daily maintenance dose of clopidogrel with a $180 \mathrm{mg}$ loading dose and $90 \mathrm{mg}$ twice daily maintenance dose of ticagrelor, showed a significant reduction in the composite primary endpoint of cardiovascular deaths, acute myocardial infarction and non-fatal strokes $(9.8 \%$ ticagrelor group versus $11.7 \%$ clopidogrel group; $p<0.001$ ), mainly driven by a reduction of deaths $(4.0 \%$ versus $5.1 \%)$ and acute myocardial infarction (5.8\% versus $6.9 \%$ ). Treatment with ticagrelor was associated with significantly higher rates of bleeding not related to coronary artery bypass graft $(4.5 \%$ versus $3.8 \% ; p=0.03)$ or spontaneous bleeding $(3.1 \%$ versus $2.3 \% ; p=0.01)$. As expected, dyspnoea was more frequent in patients treated with ticagrelor $(13.8 \%$ versus $7.8 \% ; p<0.001)$, even if this was not a significant cause of treatment discontinuation. These PLATO findings were confirmed in the real-world SWEDEHEART registry, however, in SWEDEHEART, ticagrelor was preferentially used in patients with a low bleeding risk and death, and patients on ticagrelor were significantly more often assessed with coronary angiography and treated with PCI $[28,29]$.

Pre-hospital treatment with P2Y12 receptor inhibitors in STEMI was tested in the ATLANTIC trial [30], defined as administration of loading dose before coronary angiogram, to provide stronger platelet inhibition. This trial showed a significant reduction in the rate of acute stent thrombo- 
Table 4 Pharmacology of glycoprotein IIb/IIIa inhibitors

\begin{tabular}{|c|c|c|c|}
\hline & Abciximab & Eptifibatide & Tirofiban \\
\hline Trade name & ReoPro & Integrilin & Aggrastat \\
\hline Molecule & $\begin{array}{l}\text { Fragment antigen binding (Fab) } \\
\text { 7E3 }\end{array}$ & Synthetic peptide & Non-peptide mimetic \\
\hline Molecular weight (Da) & $\sim 50,000$ & $\sim 800$ & $\sim 500$ \\
\hline $\begin{array}{l}\text { Stoichiometry (drug to glycopro- } \\
\text { tein IIb/IIIa) }\end{array}$ & $\sim 1.5: 1$ & $>>100: 1$ & $>>100: 1$ \\
\hline Binding & Non-competitive & Competitive & Competitive \\
\hline \multirow[t]{2}{*}{ Half-life (h) } & Plasma: $10-15$ & Plasma: 2.0-2.5 & Plasma: $2.0-2.5$ \\
\hline & Biologic: $12-24$ & Biologic $=$ plasma & Biologic $=$ plasma \\
\hline \multirow[t]{2}{*}{ PCI dosing } & Bolus: $250 \mu \mathrm{g} / \mathrm{kg}$ & $\begin{array}{l}\text { Bolus: } 180 \mu \mathrm{g} / \mathrm{kg}^{*} \text { plus } 180 \\
\mu \mathrm{g} / \mathrm{kg} \text { (after } 10 \mathrm{~min})\end{array}$ & Bolus: $25 \mu \mathrm{g} / \mathrm{kg}$ \\
\hline & Infusion: $0.125 \mu \mathrm{g} / \mathrm{kg} / \mathrm{min}(12 \mathrm{~h})$ & Infusion: $2 \mu \mathrm{g} / \mathrm{kg} / \mathrm{min}(12-24 \mathrm{~h}) \ddagger$ & $\begin{array}{l}\text { Infusion: } 0.15 \mu \mathrm{g} / \mathrm{kg} / \mathrm{min} \text { (up to } \\
18 \mathrm{~h} \text { ) }\end{array}$ \\
\hline \multirow[t]{2}{*}{ Renal adjustment } & No & Bolus: $180 \mu \mathrm{g} / \mathrm{kg}$ & Bolus: $25 \mu \mathrm{g} / \mathrm{kg}$ \\
\hline & & Infusion: $1 \mu \mathrm{g} / \mathrm{kg} / \mathrm{min}(12-24 \mathrm{~h})$ & $\begin{array}{l}\text { Infusion: } 0.075 \mu \mathrm{g} / \mathrm{kg} / \mathrm{min} \text { (up to } \\
18 \mathrm{~h} \text { ) }\end{array}$ \\
\hline
\end{tabular}

$P C I$ percutaneous coronary intervention, $D a$ dalton

sis with no difference in major bleeding. Pre-PCI markers of coronary reperfusion did not improve with pre-hospital use of ticagrelor, whereas post-PCI reperfusion did [31]. Of note, the ESC recommends that patients undergoing primary PCI receive a combination of dual antiplatelet therapy as early as possible before angiography.

The new ESC guidelines recommend a ticagrelor $180 \mathrm{mg}$ loading dose followed by $90 \mathrm{mg}$ twice daily in all intermediate to high-risk acute coronary syndrome patients (Class I; LOE: A) (Tab. 3 and 4; [3]).

\section{Switching to clopidogrel after ticagrelor pre-treatment}

Based on PLATO data, the more potent P2Y12 inhibitor ticagrelor is preferred over clopidogrel in the STEMI setting (Fig. 2). However, a recently published Dutch observational study (40\% STEMI patients) demonstrated (based on a propensity score-adjusted multivariate analysis) that in the era of current second-generation drug-eluting stents treatment with ticagrelor compared with clopidogrel was an independent predictor of net adverse clinical and cerebral events (NACCE) and major bleeding [32]. Furthermore, in the TOPIC study patients with acute coronary syndrome treated with PCI were randomised after one month of dual antiplatelet therapy with ticagrelor, to continued treatment with ticagrelor until 12 months, or to switching to clopidogrel. The main outcome consisted of a net clinical benefit for the switched group, primarily driven by a significantly higher bleeding risk in patients on a continued potent P2Y12 inhibitor [33].

\section{Prasugrel versus ticagrelor}

There are no studies in which the impact of ticagrelor versus prasugrel on outcome in patients with STEMI was tested directly. An adjusted indirect comparison meta-analysis [34] of prasugrel versus ticagrelor in patients with acute coronary syndrome has shown that both drugs are superior to clopidogrel. Head-to-head comparison suggests similar efficacy and safety of prasugrel and ticagrelor, but prasugrel appears more protective against stent thrombosis, especially in the early phase of post-stent implantation.

\section{Cangrelor}

Cangrelor is an intravenous direct-acting $\mathrm{P} 2 \mathrm{Y} 12$ blocker with an almost immediate antiplatelet effect, a plasmatic half-life of 3-5 min and rapid restoration of platelet function just $1 \mathrm{~h}$ after infusion cessation. The large CHAMPION series, including STEMI patients in CHAMPION PCI and CHAMPION PHOENIX, showed by pooled analysis [35] a significant reduction in stent thrombosis at 30 days $(0.9 \%$ versus $1.3 \%, p=0.0027)$. We certainly need future large trials to evaluate the safety and benefits of cangrelor in primary therapy, especially as upstream therapy with the aim of abortion of infarction. The Food and Drug Administration (FDA) and the European Medical Agency (EMA) have approved the use of cangrelor $(30 \mu \mathrm{g} / \mathrm{kg}$ bolus plus $4 \mu \mathrm{g} / \mathrm{kg} / \mathrm{min}$ infusion initiated before PCI and continued for $\geq 2 \mathrm{~h}$ or for the duration of PCI, whichever is longer) for clinical use by as adjunct therapy to PCI for reducing the risk of peri-procedural myocardial infarction, repeat coronary revascularisation, and stent thrombosis in patients who have not been treated with an oral P2Y12 receptor antago- 


\title{
Advertisement placed here.
}

\author{
SCS bohn \\ stafleu \\ CL van loghum \\ Springer Media
}

Houten 2018 


\title{
Advertisement placed here.
}

\author{
SCS bohn \\ stafleu \\ CL van loghum \\ Springer Media
}

Houten 2018 

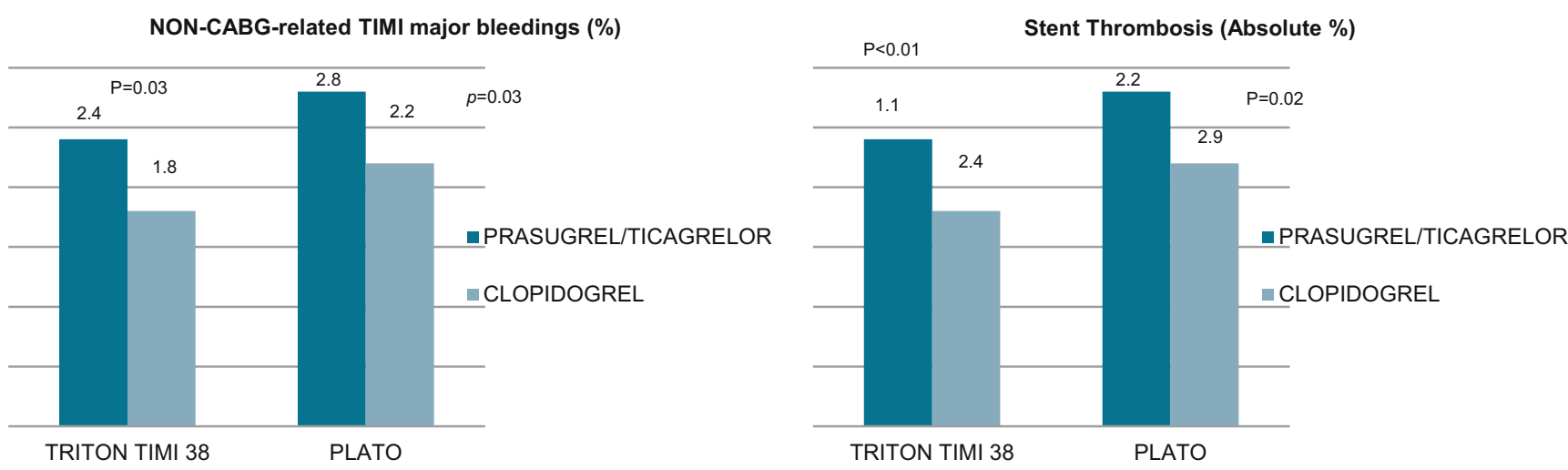

NON-CABG-related TIMI major bleedings (Relative Risk Increase)

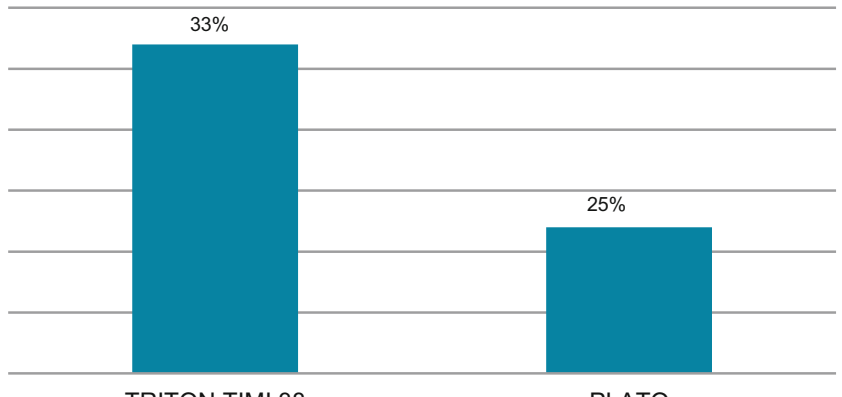

TRITON TIMI 38

PLATO

Stent Thrombosis (Relative Risk Reduction)

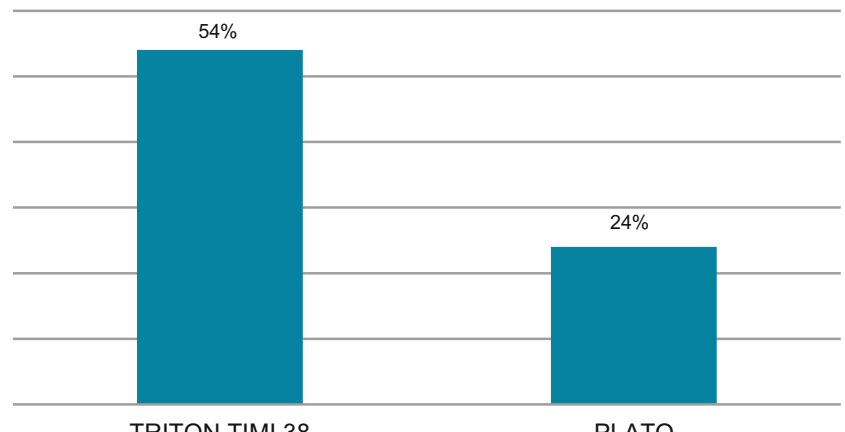

TRITON TIMI 38

PLATO

Fig. 2 Antiplatelet therapy outcomes in major trials. $C A B G$ coronary artery bypass grafting, $T I M I$ thrombolysis in myocardial infarction

nist and are not being given a glycoprotein IIb/IIIa inhibitor. Cangrelor may be considered in patients who have not received P2Y12 receptor inhibitors according to current ESC guidelines (Class IIb; LOE: A) [3].

\section{Glycoprotein IIb/IIla inhibitors (GPIs)}

GPIs can be classified into two groups: small (eptifibatide, tirofiban) and non-small (abciximab) molecules, which are characterised by different pharmacological properties (Tab. 4). They target the final pathway of platelet aggregation, competing with von Willebrand factor and fibrinogen for glycoprotein IIb/IIIa receptor binding and provide fast and potent antiplatelet effects. There are several randomised trials examining abciximab versus placebo without potent P2Y12 inhibitors in STEMI (RAPPORT, ADMIRAL, ISAR-2, CADILLAC, and ACE trial). In a meta-analysis of these trials, abciximab was associated with significant reductions in mortality at 30 days and 6 to 12 months and in re-infarction at 30 days [36]. In addition, there was no increase in bleeding. In the past few years several other GPI trials (ON-TIME 2 trial, HORIZONS-AMI trial, FINESSE) were conducted, with conflicting results. The last two GPI trials, EUROMAX and MATRIX, investigated GPI and heparin versus bivalirudin and were discussed in the bivalirudin section.
Use of GPI has waned by the introduction of new P2Y12 inhibitors. However, recent data have clearly shown a delayed onset of action of both prasugrel and ticagrelor [37].

In our opinion GPI can be recommended as early as possible (upstream strategy) among high-risk STEMI patients, such as those with advanced Killip class or anterior myocardial infarction, and those presenting within the first three hours after symptom onset [38, 39].

This was also shown in several pre-specified sub-analyses in the ON-TIME 2 trial.

The ON-TIME 2 randomised trial showed that when tirofiban is administered in the pre-hospital setting as double bolus in association with $600 \mathrm{mg}$ clopidogrel, aspirin, and heparin this results in beneficial effects in terms of an average reduction of the ST-segment $1 \mathrm{~h}$ after primary PCI and better clinical outcome at 1 year compared with placebo $[40,41]$.

Moreover, pre-hospital administration of tirofiban reduces initial thrombus burden, improves initial patency of the infarct-related vessel before primary PCI, and suggests that pre-hospital use is superior to provisional use as a bailout strategy [42-44].

Based on the INFUSE-AMI trial [45] (reduction in infarct size at day 30 on magnetic resonance imaging) and AIDA-4 trial [46] (borderline reduction in heart failure), the 
Fig. 3 Proposed algorithms for the choice of antithrombotic therapy in STEMI patients undergoing primary PCI. STEMI ST-elevation myocardial infarction, $P P C I$ primary percutaneous coronary intervention, $U F H$ unfractionated heparin, $P C I$ percutaneous coronary intervention, $L D$ low dose, $D A P T$ dual antiplatelet therapy, GPI glycoprotein IIb/IIIa inhibitor

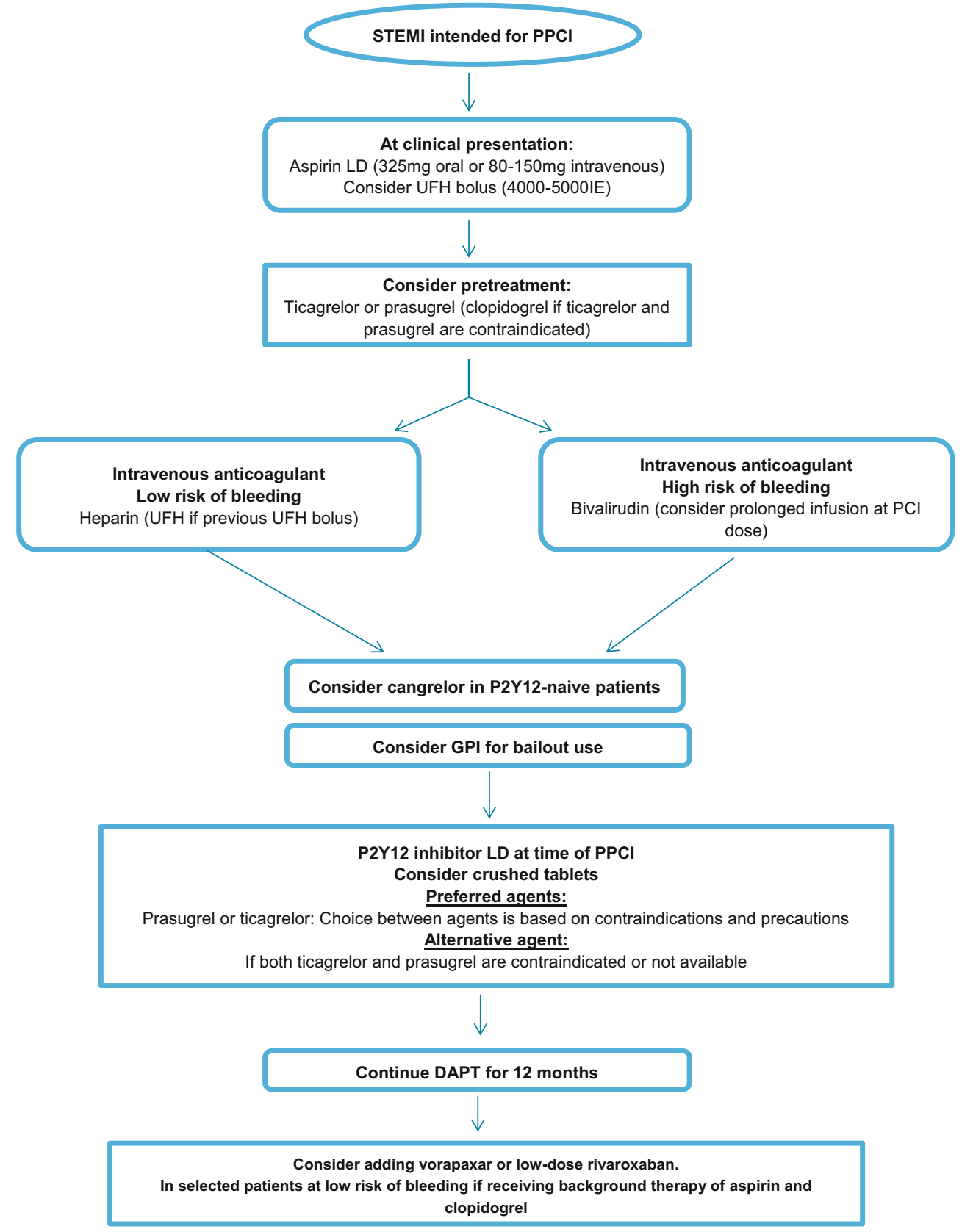

intra-coronary route may be considered, but the intravenous route should remain the standard of care for administration of GPIs.

In the end, as determined by the ESC guidelines [3], routine use or upstream use of GPI is not included in the guidelines anymore. Using GPI as bailout therapy in the event of angiographic evidence of a large thrombus, slow flow/no-reflow phenomenon or other thrombotic complications is recommendable, although this strategy has not been tested in randomised trials.

\section{Antithrombotic therapy after STEMI}

Vorapaxar Protease-activated receptors (PARs) are a family of guanine nucleotide-binding proteins- ( $G$ proteins-) coupled receptors, and PAR1 and PAR4 are expressed on human platelets. The only PAR1 antagonist that has completed phase III clinical investigations and is available for clinical use is vorapaxar. Vorapaxar is a synthetic tricyclic 3-phenylpyridine that is an analogue of himbacine, and after oral administration, vorapaxar is rapidly absorbed with high bioavailability and a long half-life [47]. 
The TRACER trial was conducted in patients with NSTEMI and did not show a favourable balance between efficacy and bleeding with vorapaxar in acute management [48].

The TRA $2^{\circ} \mathrm{P}$-TIMI 50 trial [49] was a secondary prevention trial designed to investigate the efficacy and safety of vorapaxar in the reduction of atherothrombotic events in patients with established atherosclerosis receiving aspirin and/or clopidogrel. Patients $(n=26,449)$ were randomly assigned to vorapaxar $2.5 \mathrm{mg}$ daily or placebo. After a median follow-up of 30 months, vorapaxar significantly reduced the primary endpoint (death from cardiovascular causes, myocardial infarction, or stroke) by $13 \%$ compared with placebo, driven by a $17 \%$ reduction in the rate of myocardial infarction, at the expense of a significant increase in moderate or severe bleeding and a twofold increase in intracranial bleeding. Particularly in patients with previous STEMI $(n=9,248)$, vorapaxar led to a significant $27 \%$ reduction in the risk of cardiovascular death, myocardial infarction or stroke. The efficacy and safety of vorapaxar in combination with prasugrel and ticagrelor has not been tested. Future studies with different antiplatelet combinations, duration and doses are needed to clarify if vorapaxar has a role in the treatment of patients with STEMI. Vorapaxar $(2.08 \mathrm{mg}$ once daily maintenance dose) is currently approved by the FDA and EMA for the reduction of thrombotic events in patients with a history of myocardial infarction or peripheral arterial disease (Tab. 3).

Rivaroxaban Rivaroxaban is a factor $\mathrm{Xa}$ inhibitor which does not require an antithrombin cofactor for its activity. In the setting after acute coronary syndrome (the ATLAS ACS-2 trial) $2.5 / 5 \mathrm{mg}$ rivaroxaban twice daily combined with acetylsalicylic acid or acetylsalicylic acid plus clopidogrel demonstrated a statistically significant reduction of death from cardiovascular causes, myocardial infarction or stroke compared with placebo in patients after acute coronary syndrome [50]. However, there was also a reduction in all-cause and cardiovascular mortality, with an increased risk of major bleeding and intracranial bleeding but not of fatal bleeding. More recently, the GEMINI-ACS 1 trial, a phase 2 trial, [51] showed that a dual pathway antithrombotic therapy approach combining low-dose rivaroxaban ( $2.5 \mathrm{mg}$ twice daily) with a P2Y12 inhibitor in the treatment of patients with acute coronary syndrome had a similar risk of clinically significant bleeding as aspirin and a P2Y12 inhibitor.

In patients with atrial fibrillation undergoing PCI, rivaroxaban may be considered as a therapeutic option as recently published in the PIONEER-AF trial [52]. Furthermore, in patients with stable angina, those assigned to rivaroxaban ( $2.5 \mathrm{mg}$ twice daily) plus aspirin had better cardiovascular outcomes and more major bleeding events than those assigned to aspirin alone [53]. In patients with a low bleeding risk who receive aspirin and clopidogrel, lowdose rivaroxaban ( $2.5 \mathrm{mg}$ twice daily) may be considered (Class 2b; LOE: B for both) as determined by the ESC guidelines (Tab. 3; [3]).

\section{Discussion}

The rationale for use of oral antithrombotic agents in the therapy of STEMI patients is modulating the effects of thrombin on both coagulation cascade and platelet aggregation, as well as lowering thrombotic complications, without increasing serious bleeding (Fig. 3). In patients with a low bleeding risk, the use of heparin, with or without GPI, as an anticoagulant seems to be cost-effective and has been associated with better clinical outcome. For patients not receiving upstream unfractionated heparin, enoxaparin can be considered as an alternative anticoagulant. In patients with a high bleeding risk bivalirudin should be considered. We need a strategy to reduce the risk of acute stent thrombosis if bivalirudin is used, such as an initial bolus of unfractionated heparin or prolonged infusion at PCI for up to $4 \mathrm{~h}$ after reperfusion.

With regard to antiplatelet therapy in STEMI, the recommend first-line P2Y12 inhibitors in the setting of primary PCI are prasugrel and ticagrelor [1-4]. Pre-treatment with P2Y12 inhibitors in STEMI has been tested in the ATLANTIC trial [27] and showed a significant reduction in the rate of acute stent thrombosis with no difference in major bleeding. However, pre-PCI markers of coronary reperfusion did not improve with pre-hospital use of ticagrelor. Nevertheless, in our opinion a loading dose of aspirin and potent P2Y12 inhibitors (ticagrelor or prasugrel) should be given as early as possible (upstream strategy) in STEMI patients. Maybe it is better to give the potent P2Y12 inhibitors crushed [54, 55] as it is effective and safe; pre-hospital feasibility will be tested in the Netherlands in the near future (ONTIME-3 trial, clinicaltrials.gov nr NCT03400267). Clopidogrel use is reserved for patients when prasugrel or ticagrelor is contraindicated. However, there are several clinical conditions commonly associated with an inability to achieve adequate platelet inhibition with oral use of P2Y12 receptor inhibition, for example inability to swallow, nausea, shock and intubation.

For patients with these clinical conditions cangrelor is an option. It showed an enhanced platelet inhibition when administered in addition to prasugrel or ticagrelor therapy, but the clinical benefit of its use in addition to these agents should be tested in a pre-hospital STEMI trial.

Especially in high-risk STEMI patients, early GPI use may be considered as upstream therapy. However, there is no definitive answer regarding the current role of routine 
upstream use of GPI in primary PCI in the era of potent dual antiplatelet therapy, particularly when ticagrelor or prasugrel is used. The peri-procedural administration of GPI may be based on thrombus burden or in case with impaired haemodynamic conditions.

\section{Conclusions}

Selecting the right antiplatelet and antithrombotic agents is of paramount importance in the treatment of STEMI patients undergoing primary PCI. New agents allow a reduction in rates of clinical events, including mortality, but this benefit may be reduced by the higher bleeding risk in some patients. Therefore, adjunctive pharmacotherapy should be tailored to the individual patient, based on assessment of ischaemic and bleeding risk. In this approach we decide on the optimal agent but also on the timing (prehospital, in catheterisation laboratory before angiography, or in catheterisation laboratory after angiography) and the means of administration (intravenous, intracoronary administration).

Conflict of interest R.S. Hermanides, S. Kilic and A.W.J. van't Hof declare that they have no competing interests.

Open Access This article is distributed under the terms of the Creative Commons Attribution 4.0 International License (http:// creativecommons.org/licenses/by/4.0/), which permits unrestricted use, distribution, and reproduction in any medium, provided you give appropriate credit to the original author(s) and the source, provide a link to the Creative Commons license, and indicate if changes were made.

\section{References}

1. O'Gara PT, Kushner FG, Yancy CW, et al. 2013 ACCF/AHA guideline for the management of ST elevation myocardial infarction: a report of the American College of Cardiology Foundation/American Heart Association Task Force on Practice Guidelines. J Am Coll Cardiol. 2013;61:485-510.

2. Levine GN, Bates ER, Ting HH, et al. 2011 ACCF/AHA/SCAI guideline for percutaneous coronary intervention. A report of the American College of Cardiology Foundation/American Heart Association Task Force on Practice Guidelines and the Society for Cardiovascular Angiography and Interventions. Circulation. 2011;124:574-651.

3. Ibanez B, James SK, Widimský P, et al. 2017 ESC Guidelines for the management of acute myocardial infarction in patients presenting with ST segment elevation. Eur Heart J. 2017; https://doi.org/ 10.1093/eurheartj/ehx393.

4. Windecker S, Kolh P, Witkowski A, et al. 2014 ESC/EACTS Guidelines on myocardial revascularization: the Task Force on myocardial revascularization of the European Society of Cardiology (ESC) and the European Association for Cardio-Thoracic Surgery (EACTS) developed with the special contribution of the European Association of Percutaneous Cardiovascular Interventions (EAPCI). Eur Heart J. 2014;35:2541-619.

5. Davì G, Patrono C. Platelet activation and atherothrombosis. N Engl J Med. 2007;357:2482-94.
6. Garcia DA, Baglin TP, Samama MM, et al. Parenteral anticoagulants: antithrombotic therapy and prevention of thrombosis, 9th ed: American College of Chest Physicians Evidence-Based Clinical Practice Guidelines. Chest. 2012;141:24S-43S.

7. Montalescot G, Zeymer U, Vicaut E, et al. Intravenous enoxaparin or unfractionated heparin in primary percutaneous coronary intervention for ST elevation myocardial infarction: the international randomised open-label ATOLL trial. Lancet. 2011;378:693-703.

8. Yusuf S, Mehta SR, Fox KA, et al. Effects of fondaparinux on mortality and reinfarction in patients with acute ST-segment elevation myocardial infarction: the OASIS- 6 randomized trial. JAMA. 2006;295:1519-30.

9. Stone GW, Witzenbichler B, Mehran R, et al. Bivalirudin during primary PCI in acute myocardial infarction. $\mathrm{N}$ Engl $\mathrm{J}$ Med. 2008;358:2218-30.

10. Mehran R, Lansky AJ, Stone G, et al. HORIZONS-AMI Trial Investigators. Bivalirudin in patients undergoing primary angioplasty for acute myocardial infarction (HORIZONS-AMI): 1-year results of a randomised controlled trial. Lancet. 2009;374:1149-59.

11. Stone GW, Witzenbichler B, Mehran R, et al. HORIZONS-AMI Trial Investigators. Heparin plus a glycoprotein IIb/IIIa inhibitor versus bivalirudin monotherapy and paclitaxel-eluting stents versus bare-metal stents in acute myocardial infarction (HORIZONSAMI): final 3-year results from a multicentre, randomised controlled trial. Lancet. 2011;377:2193-204.

12. Steg PG, van 't Hof AWJ, Goldstein P, et al. Bivalirudin started during emergency transport for primary PCI. N Engl J Med. 2013;369:2207-17.

13. Stone GW, Mehran R, Steg PG, et al. Bivalirudin versus heparin with or without glycoprotein IIb/IIIa inhibitors in patients with STEMI undergoing primary percutaneous coronary intervention: pooled patient-level analysis from the HORIZONS-AMI and EUROMAX trials. J Am Coll Cardiol. 2015;65:27-38.

14. Leonardi S, Frigoli E, Windecker S, et al. Bivalirudin or unfractionated heparin in patients with acute coronary syndromes managed invasively with and without ST elevation (MATRIX): randomised controlled trial. BMJ. 2016;354:i4935.

15. Fabris E, Kilic S, van 't Hof AWJ, et al. One-year mortality for bivalirudin vs heparin plus optional glycoprotein IIb/IIIa inhibitor treatment started in the ambulance for ST-segment elevation myocardial infarction: a secondary analysis of the EUROMAX randomized clinical trial. JAMA Cardiol. 2017;2:791-6.

16. Erlinge D, Omerovic E, James S, et al. Bivalirudin versus Heparin monotherapy in myocardial infarction. N Engl J Med. 2017;377: 1132-42.

17. Patrono C, Garcia Rodríguez G, Baigent C, et al. Low-dose aspirin for the prevention of atherothrombosis. $\mathrm{N}$ Engl $\mathrm{J}$ Med. 2005;353:2373-83.

18. ISIS-2. Randomised trial of intravenous streptokinase, oral aspirin, both, or neither among 17,187 cases of suspected acute myocardial infarction: ISIS-2. (Second International Study of Infarct Survival) Collaborative Group. Lancet. 1988;2:349-60.

19. Baigent C, Blackwell L, Zanchetti A, et al. Aspirin in the primary and secondary prevention of vascular disease: collaborative meta-analysis of individual participant data from randomised trials. Lancet. 2009;373:1849-60.

20. Mehta SR, Tanquay JF, Yusuf S, et al. Double-dose versus standard-dose clopidogrel and high-dose versus low-dose aspirin in individuals undergoing percutaneous coronary intervention for acute coronary syndromes (CURRENT-OASIS 7): a randomised factorial trial. Lancet. 2010;376:1233-43.

21. Gent M, Beaumont D, Messa LG, et al. A randomised, blinded, trial of clopidogrel versus aspirin in patients at risk of ischaemic events (CAPRIE). CAPRIE Steering Committee. Lancet. 1996;348: 1329-39. 
22. Yusuf S, Zhao F, Fox KK, et al. Effects of clopidogrel in addition to aspirin in patients with acute coronary syndromes without STsegment elevation. N Engl J Med. 2001;345:494-502.

23. Angiolillo DJ, Fernandez-Ortiz A, Costa MA, et al. Variability in individual responsiveness to clopidogrel: clinical implications, management, and future perspectives. J Am Coll Cardiol. 2007;49:1505-16.

24. Bergmeijer TO, Janssen PW, ten Berg JM, et al. CYP2C19 genotype-guided antiplatelet therapy in ST-segment elevation myocardial infarction patients-Rationale and design of the Patient Outcome after primary PCI (POPular) Genetics study. Am Heart J. $2014 ; 168: 16-22$.

25. Wiviott SD, Trenk D, Braunwald E, et al. Prasugrel compared with high loading-and maintenance-dose clopidogrel in patients with planned percutaneous coronary intervention: the prasugrel in comparison to clopidogrel for inhibition of platelet activation and aggregation thrombolysis in myocardial infarction 44 trial. Circulation. 2007;116:2923-32.

26. Montalescot G, Wiviott SD, Antman EM, et al. Prasugrel compared with clopidogrel in patients undergoing percutaneous coronary intervention for ST elevation myocardial infarction (TRITON-TIMI 38): double-blind, randomised controlled trial. Lancet. 2009;373:723-31.

27. Wallentin L, Becker RC, Harrington RA, et al. Ticagrelor versus clopidogrel in patients with acute coronary syndromes. N Engl J Med. 2009;361:1045-57.

28. Sahlén A, Varenhorst C, Jernberg T, et al. Outcomes in patients treated with ticagrelor or clopidogrel after acute myocardial infarction: experiences from SWEDEHEART registry. Eur Heart J. 2016;37:3335-42.

29. Sahlén A, Varenhorst C, Jernberg T, et al. Contemporary use of ticagrelor in patients with acute coronary syndrome: insights from Swedish web system for enhancement and development of evidence-based care in heart disease evaluated according to recommended therapies (SWEDEHEART). Eur Heart J Cardiovasc Pharmacother. 2016;2:5-12.

30. Montalescot G, van 't Hof AWJ, Hamm CW, et al. Prehospital ticagrelor in ST-segment elevation myocardial infarction. N Engl J Med. 2014;371:1016-27.

31. ATLANTIC investigators, Fabris E, van 't Hof AWJ, Montalescot $\mathrm{G}$, et al. Clinical impact and predictors of complete ST segment resolution after primary percutaneous coronary intervention: A subanalysis of the ATLANTIC Trial. Eur Heart J Acute Cardiovasc Care. 2017; https://doi.org/10.1177/2048872617727722.

32. Zocca P, Liefke C, von Birgelen C, et al. Clopidogrel or ticagrelor in acute coronary syndrome patients treated with newer-generation drug-eluting stents: CHANGE DAPT. EuroIntervention. 2017;13(10):1168-76.

33. Cuisset T, Deharo P, Bonnet JL, et al. Benefit of switching dual antiplatelet therapy after acute coronary syndrome: the TOPIC (timing of platelet inhibition after acute coronary syndrome) randomized study. Eur Heart J. 2017; https://doi.org/10.1093/eurheartj/ehx175.

34. Biondi-Zoccai G, Lotrionte M, Sheiban I, et al. Adjusted indirect comparison meta-analysis of prasugrel versus ticagrelor for patients with acute coronary syndromes. Int J Cardiol. 2011;150:325-31.

35. Steg PG, Bhatt DL, Harrington RA, et al. Effect of cangrelor on periprocedural outcomes in percutaneous coronary interventions: a pooled analysis of patient-level data. Lancet. 2013;382:1981-92.

36. De Luca G, Suryapranata H, Stone GW, et al. Abciximab as adjunctive therapy to reperfusion in acute ST-segment elevation myocardial infarction: a meta-analysis of randomized trials. JAMA. 2005;293:1759-65.

37. FABOLUS PRO Investigators, Valgimigli M, Tebaldi M, Ferrari R, et al. Prasugrel versus tirofiban bolus with or without short postbolus infusion with or without concomitant prasugrel administration in patients with myocardial infarction undergoing coronary stenting: the FABOLUS PRO (Facilitation through Aggrastat By drOpping or shortening Infusion Line in patients with ST-segment elevation myocardial infarction compared to or on top of PRasugrel given at loading dOse) trial. JACC Cardiovasc Interv. 2012;5:268-77.

38. De Luca G, Savonitto S, Suryapranata H, et al. Platelet GP IIbIIIa receptor antagonists in primary angioplasty: back to the future. Drugs. 2015;75:1229-53.

39. Savonitto S, De Luca G, Bolognese L, et al. Antithrombotic therapy before, during and after emergency angioplasty for ST elevation myocardial infarction. Eur Heart J: Acute Cardiovasc Care. 2017;6:173-90.

40. van 't Hof AWJ, ten Berg J, Hamm C, et al. Prehospital initiation of tirofiban in patients with ST elevation myocardial infarction undergoing primary angioplasty (On TIME 2): a multicentre, doubleblind, randomised controlled trial. Lancet. 2008;372:537-46.

41. ten Berg JM, van 't Hof AWJ, Hamm C, et al. On behalf of the Ongoing Tirofiban In Myocardial infarction Evaluation (On-TIME) 2 study group. Effect of early, pre-hospital initiation of high-bolus dose tirofiban in patients with ST-segment elevation myocardial infarction on short and long-term clinical outcome. J Am Coll Cardiol. 2010;55:2446-55.

42. Heestermans AA, Van Werkum JW, van 't Hof AWJ, et al. Marked reduction of early stent thrombosis with pre-hospital initiation of high-dose Tirofiban in ST-segment elevation myocardial infarction. J Thromb Haemost. 2009; 7:1612-8.

43. Hermanides RS, van Werkum JW, van 't Hof AWJ, et al. The effect of pre-hospital glycoprotein IIb-IIIa inhibitors on angiographic outcome in STEMI patients who are candidates for primary PCI. Catheter Cardiovasc Interv. 2012;79:956-64.

44. Hermanides RS, Heestermans AA, van 't Hof AWJ, et al. Highdose tirofiban pretreatment reduces the need for bail-out study medication in patients with ST-segment elevation myocardial infarction: results of a subgroup analysis of the On-TIME 2 trial. Heart. 2011;97:106-11.

45. Stone GW, Maehara A, Gibson CM, et al. Intracoronary abciximab and aspiration thrombectomy in patients with large anterior myocardial infarction: the INFUSE-AMI randomized trial. JAMA. 2012;307:1817-26.

46. Thiele H, Wohrle J, Schuler G, et al. Intracoronary versus intravenous bolus abciximab during primary percutaneous coronary intervention in patients with acute ST-elevation myocardial infarction: a randomised trial. Lancet. 2012;379:923-31.

47. Franchi F, Rollini F, Angiolillo DJ, et al. Platelet thrombin receptor antagonism with vorapaxar: pharmacology and clinical trial development. Future Cardiol. 2015;11:547-64.

48. Tricoci P, Huang Z, Mahaffey KW, et al. Thrombin-receptor antagonist vorapaxar in acute coronary syndromes. N Engl J Med. 2012;366:20-33.

49. Scirica BM, Bonaca MP, Morrow DA, et al. Vorapaxar for secondary prevention of thrombotic events for patients with previous myocardial infarction: a prespecified subgroup analysis of the TRA $2{ }^{\circ} \mathrm{P}$ TIMI 50 trial. Lancet. 2012;380:1317-24.

50. Mega JL, Braunwald E, Gibson CM, et al. Rivaroxaban in patients stabilized after a ST segment elevation myocardial infarction: results from the ATLAS ACS 2 TIMI 51 trial (Anti Xa therapy to lower cardiovascular events in addition to standard therapy in subjects with acute coronary syndrome-thrombolysis in myocardial infarction). J Am Coll Cardiol. 2013;61:1853-9.

51. Ohman EM, Roe MT, Gibson CM, et al. Clinically significant bleeding with low-dose ribvaroxaban versus aspirin, in addition to P2Y12 inhibition, in acute coronary syndromes (GEMINIACS-1): a double-blind, multicentre, randomised trial. Lancet. 2017;389:1799-808.

52. Gibson CM, Mehran R, Fox KA, et al. Prevention of bleeding in patients with atrial fibrillation undergoing PCI. N Engl J Med. 2016;375:2423-34. 
53. Eikelboom JW, Connoly SJ, Bosch J, et al. Rivaroxaban with or without aspirin in stable cardiovascular disease. N Engl J Med. 2017; https://doi.org/10.1056/NEJMoa1709118.

54. Parodi G, Xanthopoulou I, Alexopoulos D, et al. Ticagrelor crushed tablets administration in STEMI patients: the MOJITO study. J Am Coll Cardiol. 2015;65:511-2.
55. Rollini F, Franchi F, Angiolillo DJ, et al. Crushed prasugrel tablets in patients with STEMI undergoing primary percutaneous coronary intervention. The CRUSH study. J Am Coll Cardiol. 2016;67:1994-2004. 